\title{
Mind the Working-Class People! An African Reading of Leviticus 25:8-55 with Latino/a Critical Tools
}

\author{
NDIKHO MTSHISELWA (UNISA)
}

\begin{abstract}
It is generally accepted by Latino/a biblical scholars, namely, Fernando F. Segovia and Alejandro F. Botta, among others, that both the historical-critical methods and the contextual approaches are equally important in the reading of the HB. First, this paper argues that Lev 25:8-55 contains verses (cf. Lev 25:10, 39-40 and 54-55) which are ascribed to the Deuteronomistic writers (D) but which were re-used by the authors of the Holiness Code (H). Second, because the absolute noun, שָָׁכִיר "hired labourer" and the qal verb, עבד "to work" in Lev 25:40 refer to the working-class people, the context(s) from which the text of Lev 25:8-55 emerged will be investigated in relation to the working-class people. Third, the paper probes the relevance of Lev 25:8-55 to Ernesto "Che" Guevara's discourse of the experiences of the working-class people and Segovia's reading of the $H B$ in the light of such experiences. It is argued in this paper that H's concern for social justice for the workingclass people can throw light on the reading of the ancient texts, particularly from the perspective of the Latino/a biblical criticism, and more importantly, that such a reading could also have implications for the working-class people of South Africa.
\end{abstract}

\section{KEYWORDS:}

Leviticus 25, Holiness Code, Latino/a biblical criticism, working-class, justice, South Africa.

\section{A INTRODUCTION}

Umama wami, ekhishini (My mother, in the kitchen)

Bambiza bani, ekhishini (Who do they call her, in the kitchen?)

Bambiz' uJeyi, ekhishini (They call her Jeyi, in the kitchen)

Bambiz'ugeli, ekhishini (They call her girl, in the kitchen)

Ubaba wami, engadini (My father, in the garden)

Bambiza bani, engadini (Who do they call him, in the garden?)

Bambiz' upikinini, engadini (They call him Pikinini, in the garden)

Bambiz'uboyi, engadini (They call him boy, in the garden)

Lelizwe ngelethu, (This land is ours)

Article submitted: 17/07/2015; article accepted: 15/02/2016. Ndikho Mtshiselwa, "Mind the Working-Class People! An African Reading of Leviticus 25:8-55 with 
Basebenzi masihlanganeni (Working-class people, let us unite) (6x)

Kudala sisebenzel' amabhulu, (We have been working for the Boers far too long)

Basebenzi masihlanganeni (Working-class people, let us unite) (6x)

When the black South African masses sang this indigenous (Zulu) song, namely Lelizwe ngelethu, (This land is ours) in the heyday of colonisation and apartheid, the aim was not only to articulate the experiences of the workingclass people who serve as domestic workers and gardeners, but to equally call for socio-economic justice. Interestingly, the song is sung by the children of the domestic workers and the garden workers who are also part of the workingclass people since they call for unity with the statement Basebenzi masihlanganeni "Working-class people let us unite." The song is also sung by the so-called working-class "slaves" in Marikana and in other mines that are owned by the white economic oligarch and black political elites. The declaration Lelizwe ngelethu, "This land is ours" expresses a claim to the land by the working-class people. The claim reveals that the younger generation is aware of the historical land dispossession that was perpetrated through the colonial and apartheid systems. For the working-class people, their experience of injustice is linked to the subject of landlessness. This brings to mind Mosala's claim that the colonists "dispossessed the Africans of their land and created out of them a wage class with nothing but their labour power to sell." The claim is supported by the lament Kudala sisebenzel' amabhulu, "We have been working for the Boers far too long." First, the working-class people undoubtedly lost their land to the Boers; second, they became poor; and third, they were forced by the situation of poverty to work for the Boers. The experiences of the working-class people that are articulated in the song under consideration bring to mind, in turn, the experiences of the working-class people which are expressed in Lev 25:8-55.

With respect to the text of Lev 25:8-55, land dispossession created out of the poor Israelites indebtedness and a working-class citizens with nothing but their labour power to sell. Noteworthy, it is widely accepted that the concerns about the adverse effects that one's ethical behaviours has on other people, specifically the poor, constitutes one of the distinct features of the Holiness Code $(\mathrm{H}){ }^{2}$ Drawing on the preceding consensus, it is argued in this paper that

Latino/a Critical Tools," OTE 29/1 (2016): 133-150. DOI: http://

dx.doi.org/10.17159/2312-3621/2016/v29n1a9

1 Itumeleng J. Mosala, "Land, Class and the Bible in South Africa Today," JBTSA 5/2 (1991): 40.

2 Israel Knohl, The Sanctuary of Silence: The Priestly Torah and the Holiness School (Minneapolis: Fortress Press, 1995), 175-180; John J. Collins, Introduction to the Hebrew Bible (Minneapolis: Fortress Press, 2004), 146, 151. For an illustration of H's concern for social justice see Christophe Nihan, From Priestly Torah to Pentateuch: A Study in the Composition of the Book of Leviticus (Tübingen: Mohr Siebeck, 2007), 521; Christophe Nihan, "Resident Aliens and Natives in the Holiness Legisla- 
H's concern for social justice for the working-class people can throw light on the reading of the ancient texts, particularly from the perspective of the Latino/a biblical criticism, and more importantly, that such a reading could also have implications for the working-class people of South Africa. In addition, this argument is based on the experiences of the working-class people of South Africa as well as on the trajectory of Latino/a biblical criticism that is articulated by the likes of Fernando F. Segovia and Alejandro F. Botta. The discussion in this paper will follow the outline below:

- H's concern for social justice

- From H to Latino/a biblical critics

- Implications of H's concern for social justice for South Africa

\section{B H'S CONCERN FOR SOCIAL JUSTICE FOR THE WORKING- CLASS PEOPLE}

The phenomenon of innerbiblical exegesis in some of the Pentateuchal composition is indisputable. An appealing definition of innerbiblical exegesis is that of Stackert. He views it as an "interpretive revision, reuse, expansion, or application of biblical source material in subsequent biblical compositions." 3 What this means is that certain authors or redactors often re-read earlier sources with the view of articulating an interpretation to their addressees. On the issue of how earlier sources were re-read and reused, this paper argues that Lev 25:8-55 contains verses (cf. Lev 25:10, 39-40 and 54-55) which are ascribed to the Deuteronomistic writers (D) and Priestly authors (P) but which were re-used by the authors of $\mathrm{H}$. On this point, a discussion on the scribal scholarship in the formation of Lev 25:8-55 as well as the context(s) from which the text under consideration emerged is in order.

\section{Scribal Scholarship in the Formation of Leviticus 25:8-55}

Bartos and Levinson classify the noun "Jubilee" as belonging to $\mathrm{H}$ and "remission" (cf. Deut 15:1; 31:10) as belonging to D. ${ }^{4}$ H's substitution of D's noun

tion," in The Foreign and the Law: Perspectives from the Hebrew Bible and the Ancient Near East (ed. Reinhard Achenbach, Rainer Albertz and Jakob Wöhrle; Wiesbaden: Harrassowitz Verlag, 2011), 131; Leigh M. Trevaskis, Holiness, Ethics and Rituals in Leviticus (Sheffield: Sheffield Academic Press, 2011), 4.

3 Jeffrey Stackert, "Distinguishing Innerbiblical Exegesis from Pentateuchal Redaction: Leviticus 26 as a Test Case," in The Pentateuch: International Perspectives on Current Research (ed. Thomas B. Dozeman, Konrad Schmid and Baruch J. Schwartz; Tübingen: Mohr Siebeck, 2011), 371.

4 Michael Bartos and Bernard M. Levinson, “"This is the Manner of the Remission': Implicit Legal Exegesis in 11QMelchizedek as a Response to the Formation of the Torah," JBL 132/2 (2013): 354. 


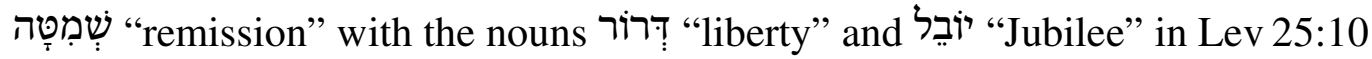
reveals an ideological contestation. Gerstenberger noted that the notion of liberty mentioned in the Israelite Jubilee was supposed to be comprehensive in that it includes both the return of land and the release of debt-slaves. ${ }^{5}$ In other words, the Israelite Jubilee was meant to attain liberation for the poor in Israel that is not only through the cancellation of debts and slavery, but equally through land redistribution. On this point, $\mathrm{H}$ contests the ideological position that the liberation of the poor could only be attained through "remission." Due to this contestation the idea of the return of land is coupled with the idea of the release of debt-slaves in the Israelite Jubilee. The land referred to in Lev 25:855 comprised of agricultural land (vv. 18, 20 and 34) and houses (vv. 29-34). It was presumed that the land that was lost or sold by the poor to the rich due primarily to their poverty and debts would be regained through the Israelite Jubilee legislation in Lev 25:8-55. ${ }^{6}$ Thus, the Israelite Jubilee can be regarded as a legislation that sought to insure and advocate socio-economic freedom for the Israelites particularly the poor class. If one considers the repetition of the

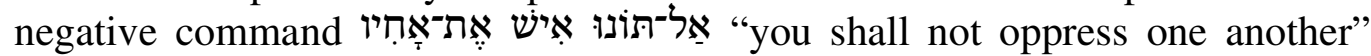
(vv. 14; 17) and of the qal imperfect third person masculine singular verb ימוּ: "becomes poor" (vv. 25; 35; 39), then, liberty in Lev 25:10 probably implied socio-economic freedom. Since the repetitions form part of the literary context of the absolute common masculine singular noun "Tị "liberty," it can be argued that socio-economic freedom in that context was aimed at alleviating poverty and redressing economic inequality.

Of vv. 39-40, the established view that $\mathrm{H}$ used other sources such as $\mathrm{D}$, among others, to create his material is noteworthy at this point. ${ }^{7}$ Leuchter's $^{\prime}$ comment on the subject of slavery is rather significant. He claims that:

5 Erhard S. Gerstenberger, Leviticus: A Commentary (Louisville, Ky.: Westminster John Knox Press, 1996), 378.

6 Frank H. Gorman, Divine Presence and Community: A Commentary on the Book of Leviticus (Grand Rapids: Wm. B. Eerdmans Publishing Company, 1997), 138; Stephen Mott and Ronald J. Sider, "Economic Justice: A Biblical Paradigm," Trans 17/2 (2000): 58; Mark F. Rooker, Leviticus (NAC 3A; Nashville: Broadman and Holman Publishers, 2000), 306; Samuel E. Balentine, Leviticus (Louisville, Ky.: Westminster John Knox Press, 2002), 195; Tamara C. Eskenazi and Andrea L. Weiss, The Torah: A Women's Commentary (New York: URJ Press and Women of Reform Judaism, 2008), 750.

7 Jeffrey Stackert, "Composition Strata in the Priestly Sabbath: Exodus 31:12-17 and 35:1-3," JHScr 11 (2011): 6; cf. Bernard M. Levinson, "The Birth of Lemma: The Restrictive Reinterpretation of the Covenant Code's Manumission Law by the Holiness Code (Leviticus 25:44-46)," JBL 124/4 (2005): 617-639; Nihan, From Priestly Torah, 616; Mark Leuchter, "The Manumission Laws in Leviticus and Deuteronomy: The Jeremiah Connection," JBL 127/4 (2008): 637; Eckart Otto, "The Holiness Code in Diachrony and Synchrony in the Legal Hermeneutics of the Pentateuch," in The 
Binding slave manumission to the fifty-year jubilee cycle is a dramatic departure from the D legislature that serves as the author's source, since in D (as well as in the earlier Covenant Code), the slave is given a six-year term of servitude with release in the seventh. ${ }^{8}$

Although Leuchter's claim appears plausible, it should be approached with caution, mainly because he does not provide textual evidence to support his view that $\mathrm{H}$ used both $\mathrm{D}$ and the $\mathrm{CC}$. In terms of the $\mathrm{CC}$, Exod 21:2 spells out a six-year term of servitude. Like the $\mathrm{CC}, \mathrm{D}$ makes reference to the noun עֶבֶד "slave" which points to slavery (Deut 5:15; 15:15, 17; 24:22; 34:5). In line with Lev 25:39-40, the noun עֶבֶד "slave" is presented in the context of a fiftyyear Jubilee cycle. In addition, an Israelite is presented as the owner of the slave or an employer. The presentation is in complete contrast to that of the CC and D. Therefore, Leuchter is quite correct to observe H's dramatic departure from the conceptualisation of slavery by CC and D. The verses of Lev 25:39-40 exhibit an ideological contestation and a re-conceptualisation of slavery by $\mathrm{H}$ which sought to substitute the six-year term by D and the $\mathrm{CC}$ with a fifty-year cycle.

Furthermore, the deliberate use of the term "slaves" which speaks to the way the Judeans were treated in the workplace and the instruction that the poor brother should not work as a slave but as "hired worker" (v. 40) show H's concern for social justice for the working-class Judeans. No doubt, the absolute noun שָׁכִִיר "hired worker" (NIV) and the qal verb work" in v. 40 refer to the class of people who were employees, that is, the working-class Judeans. It becomes clear that $\mathrm{H}$ draws on D's idea of slavery and equally departs in the way $\mathrm{H}$ upheld the concern for social justice for the working-class people in v. 40 .

What about vv. 54-55? From an ideological point of view, the provision

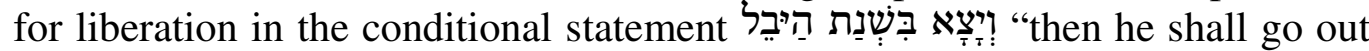
in the year of Jubilee" (v. 54) also reveals H's concern for social justice. ${ }^{9}$ However, since the release of slaves is a typical D subject, it can be assumed that $\mathrm{H}$ relied mostly on D in his construction of the concern for social justice. Further support for the assignment of v. 54 to $\mathrm{H}$ is contained in the reference to the Jubilee cycle years, which is typically H. Therefore, v. 54 indisputably belongs to $\mathrm{H}$. In the stratum of vv. 47-54 is the provision for the release of slaves which

Strata of the Priestly Writings: Contemporary Debate and Future Directions (ed. Sarah Shectman and Joel S. Baden; Zürich: Theologischer Verlag Zürich, 2009), 139; Esias E. Meyer, "From Cult to Community: The Two Halves of Leviticus," VetE 34/2 (2013): 6-7.

8 Leuchter, "Manumission Laws," 637.

9 Cf. Nihan, From Priestly Torah, 521; Nihan, "Resident Aliens," 131; Trevaskis, Holiness, 4. 
fits well with the quest and contestation for redress of socio-economic injustice echoed in Lev 25:8-55. The slaves were mostly people who lost their land and became poor as a result. Due to their poverty, they became the slaves of the rich élites. However, their economic condition did not make Yahweh to identify less with them. Slaves also belonged to Yahweh who in turn sought social justice for them, according to H's ideological perspective.

For his part, Nihan argues that Lev 25:55 and Lev 26:1 are linked with a reminiscent of the Decalogue namely the reference to the exodus which is also reflected in Exod 20:2 and Deut 5:6. ${ }^{10}$ Both Lev 25:55 and Exod 20:2 refer to being brought out of Egypt while the negative command used to prohibit the Israelites from worshipping idols in Lev 26:1 is in a Decalogue formula. In addition, both Grünwaldt and Meyer note that the fact that the Israelites are addressed as people who are already delivered from Egypt resonates with Nihan's view. ${ }^{11}$ In my view, the theme of deliverance from Egypt, though originally P's, has now been re-used by $\mathrm{H}$ in Lev 25. The theme in v. 55 which is employed in $\mathrm{v} .38$ by $\mathrm{H}$ originally belonged to the $\mathrm{P}$ stratum. It was inserted in v. 55 by $\mathrm{H}$ but it exhibits a $\mathrm{P}$ feature. With respect to Leviticus 25:55, the

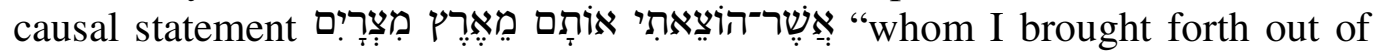
the land of Egypt" adds a curious dimension to the way P was re-used by $\mathrm{H}$.

\section{Navigating H's Concern for Social Justice in Leviticus 25:8-55}

In his discussion of the possible socio-historical context of Lev 25, Meyer ${ }^{12}$ argues in favour of a post-exilic dating of the final form of the text, since he finds attempts to date the text back to the pre-exilic period unconvincing. For Milgrom, the origins of $\mathrm{H}$ lie in the eighth century, but Meyer correctly refutes such an idea. ${ }^{13}$ Meyer further engages with Joosten and with Knohl who argue for a pre-exilic dating of $\mathrm{H}$ based on the view that the exile mentioned in Lev 26 was to Assyria and not to Babylonia. ${ }^{14}$ As Meyer rightly observes, Knohl's claim is not convincing. Like Joosten, my reluctance to follow Knohl's reasoning is because he ignores the possibility that both Lev 25 and 26 could

10 Nihan, From Priestly Torah, 537.

11 Klaus Grünwaldt, Das Heiligkeitsgesetz Leviticus 17-26: Ursprüngliche Gestalt, Tradition und Theologie (BZAW 271; Berlin: Walter de Gruyter, 1999), 380-381; Esias E. Meyer, The Jubilee in Leviticus 25: A Theological Ethical Interpretation from a South African Perspective (Münster: LIT Verlag, 2005), 224.

12 Meyer, Jubilee in Leviticus, 221-255.

13 Jacob Milgrom, "The Antiquity of the Priestly Source: A Reply to Joseph Blenkinsopp," ZAW 111 (1999): 10-22; Esias E. Meyer, "Dating the Priestly Text in the Pre-Exilic Period: Some Remarks about Anachronistic Slips and other Obstacles," VetE 31/1 (2010): 1-6; Esias E. Meyer, "Returning to an Empty Land: Revisiting my Old Argument about Jubilee," OTE 27/2 (2014): 508.

14 Meyer, Jubilee in Leviticus, 252-253; cf. Knohl, Sanctuary of Silence, 213, 223. 
refer to the Babylonian exile, even though the text refers to a liberated people. ${ }^{15}$ Meyer does not completely rule out the possibility of a late exilic dating of $\mathrm{H}$ (the second half of the sixth century B.C.E.), as proposed by Grünwaldt and by Otto who argue for a later date for $\mathrm{H}$ because $\mathrm{H}$ used earlier traditions such as $\mathrm{P}, \mathrm{CC}$ and D. ${ }^{16}$ This means that a late exilic or post-exilic dating would make sense if $\mathrm{H}$ was familiar with earlier sources, that is, with exilic sources. However, both Meyer and Grünwaldt partly support an exilic dating. Noteworthy, they decisively argue for the possibility of a post-exilic dating for two reasons.

First, based on the relationship between Lev 25 and Lev 26, both of which form part of the Holiness Code (chs. 17-26), both Meyer and Grünwaldt draw insight from Lev 26:13. The point that the Israelites are addressed as people who are already delivered sways them to consider a post-exilic dating for

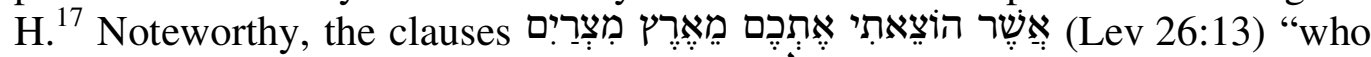

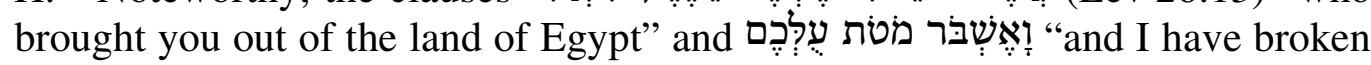
the bands of your yoke" (Lev 26:13) are said to refer to the deliverance from the Babylonian exile. In my view, the theme of deliverance from Egypt, though originally $\mathrm{P}$, as stated earlier, has now been re-used by $\mathrm{H}$ in both Lev 25 and 26. Assigning that theme to $\mathrm{H}$ justifies the identification of an implicit reference to the Babylonian exile in both Lev 25 and 26. Therefore, the post-exilic dating of $\mathrm{H}$ by both Meyer and Grünwaldt could be justified. However, more than a single argument would be needed to prove a post-exilic dating of $\mathrm{H}$.

Second, Meyer sees the fifty years of the Jubilee cycle as an attempt by the élites to counter the loss of land and reclaim it after their liberation from the Babylonian exile. ${ }^{18}$ In other words, the view that the Babylonian exile lasted for forty-nine years while liberation occurred in the fiftieth year links the reference to fifty years in the $\mathrm{H}$ stratum to the exilic context. As a result, he builds a strong argument on this view. The idea that the returning élites who wanted to reclaim land were the addressees of $\mathrm{H}$ in Lev 25 prompts Meyer to propose a post-exilic dating for $\mathrm{H}$, of course, in agreement with Grünwaldt. ${ }^{19}$ A postexilic dating of $\mathrm{H}$ based on the link of the Jubilee cycle with the forty-nine years in exile makes sense. Thus, I am inclined to support the post-exilic dating of $\mathrm{H}$, as both Meyer and Grünwaldt have convincingly shown. However, I

15 Jan Joosten, People and Land in the Holiness Code: An Exegetical Study of the Ideational Framework of the Law in Leviticus 17-26 (Supplements to Vetus Testamentum 67; Leiden: Brill, 1996), 203-207.

16 Meyer, Jubilee in Leviticus, 223; cf. Baruch J. Schwartz, The Holiness Legislation: Studies in the Priestly Code (Jerusalem: Magnes; 1996), 15; Grünwaldt, Das Heiligkeitsgesetz Leviticus, 375-381; Otto, “The Holiness Code," 139.

17 Grünwaldt, Das Heiligkeitsgesetz Leviticus, 380-381; Meyer, Jubilee in Leviticus, 224, 228; cf. Lev 26:13.

18 Meyer, Jubilee in Leviticus, 227.

19 Meyer, Jubilee in Leviticus, 224; Grünwaldt, Das Heiligkeitsgesetz Leviticus, 380-381. 
choose to differ with Meyer on the assumption that the final form of Lev 25 was constructed uniquely by $\mathrm{H}$. Due to his exclusive focus on dating $\mathrm{H}$, one is left with the impression that the whole of Lev 25, be it in its final or original form, is from the post-exilic period. However, that conclusion cannot be sustained because other sources appear in the text. Although I support a post-exilic dating for $\mathrm{H}$, this position does not apply to the whole of Lev 25. There is also a need to date other sources which were supplemented by $\mathrm{H}$, namely $\mathrm{P}$ and $\mathrm{D}$, which are behind the stratum of Lev 25. Given the dating of the stratum of Lev 25 , it is thus critical that we navigate H's concern for social justice in the world of the text production indicated here.

D's call for the payment of compensation and the distinction between the houses in villages and walled cities seem to favour the rich élites instead of the struggling farmers. Interestingly, $\mathrm{H}$ differs from $\mathrm{D}$ in that $\mathrm{H}$ 's conditional statement "But if he does not have enough (money) to restore it to himself" is more concerned about the poor especially the ones with no money. In all probability, $\mathrm{H}$ addressed both the poor and the rich but emphasised the plight of the poor. In fact, $\mathrm{H}$ rejects D's motif of payment of compensation as reflected in the connected negative commands "Take no usury of him" (v. 10) and "or interest" (v. 10). Thus, it is clear that H's interest focused on the plight of the poor while D's interest was with the rich élites. For $\mathrm{H}$, poverty led to indebtedness, hence, his concern in v. 35 for social justice which had to be addressed. The verse refers to debt that was likely caused by poverty. Since H addressed both the rich returnees from the Babylonian exile and the poor who were not deported to Babylonia, one could agree with Meyer's claim that the addressees of Lev 25 were the wealthy élite returnees from exile who had money and the support of the Persian Empire. ${ }^{20}$ However, I would not rule out the presence of the poor people in the post-exilic period as Meyer has done. That is, the addressees of Lev 25 were not merely the wealthy élite returnees from exile.

On the features that were re-conceptualised by H, one could ask, if P's theme of deliverance from Egypt (vv. 42, 55) referred to the captivity that the Babylonian exile embodied, why did $\mathrm{H}$ re-use it long after the liberation from exile? Were there other forms of captivity which called for liberation in the post-exilic period, and why would $\mathrm{H}$ find it imperative to re-conceptualise "slavery" (vv. 39-40, 44-46) after the Babylonian exile, which was regarded as captivity or slavery? A few scenarios may explain H's re-conceptualisation of exilic concepts. First, as Meyer has argued, H probably only sought to remind the Israelites particularly those who were from the Babylonian exile of their history so that they could preserve it. ${ }^{21}$ This first scenario is not appealing enough, as it would not have necessitated the rewriting of that history. The second scenario is that $\mathrm{H}$ probably witnessed a situation that was similar to that of

20 Meyer, Jubilee in Leviticus, 253.

21 Meyer, Jubilee in Leviticus, 243. 
the exilic period. In other words, the Israelites encountered other forms of captivity in the post-exilic period which resembled the Babylonian exile. Hence, $\mathrm{H}$ re-conceptualised the D's idea of "slavery" and the P's theme of "deliverance from Egypt." Could it be that the Judeans in Yehud were not free after the Babylonian exile?

Brueggemann argues that the Judeans who were treated as slaves in Babylonia were equally treated as slaves by the Persian authorities in the postexilic period. $^{22}$ Based on Neh 9:33, Brueggemann explains Ezra's action in the following manner:

He describes for God the exploited status of the Jews in Jerusalem at the hands of the Persians ... For all of the generosity and support of Artaxerxes for Nehemiah, the Persians are effective tax collectors. They exploited the colony of Yehud so vigorously that Ezra can say, "we are slaves". . . The Jews are back at work in the homeland, but are exploited peasants. ${ }^{23}$

Based on this explanation, there is no doubt that the Judeans were exploited workers during the post-exilic period. Noteworthy, that the agricultural produce and wealth generated by the Judeans in post-exilic Yehud was

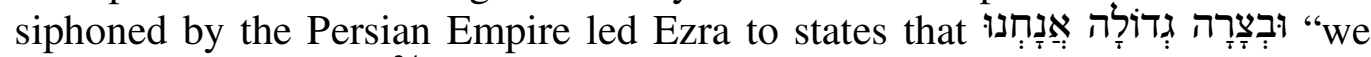
are in great distress." 24 Not only does Neh 9:36-37 suggest that the Judeans were exploited peasants or workers, but it equally reveals that the Persian imperialistic government exploited the economic resources of the Judeans in postexilic Yehud. The evidence of persistent slavery and of the socio-economic injustice which was perpetuated by the élites justified H's concern for social justice.

Based on the phenomenon of innerbiblical exegesis in some of the Pentateuchal composition, specifically Lev 25:8-55, it becomes clear that $\mathrm{H}$ re-read

22 Walter Brueggemann, Great Prayers of the Old Testament (Louisville, Westminster John Knox Press, 2008), 109; cf. Walter Brueggemann, Cadences of Home: Preaching among Exiles (Louisville, Ky.: Westminster John Knox Press, 1997), 115; Emmanuel O. Usue, "Restoration or Desperation in Ezra and Nehemiah? Implications for Africa," OTE 20/3 (2007): 843; Temba Rugwiji, "Appropriating Judean PostExilic Literature in a Postcolonial Discourse: A Case for Zimbabwe," (Ph.D. thesis, Pretoria: University of South Africa, 2013), 46.

23 Brueggemann, Great Prayers, 109; Donald P. Moffat, Ezra's Social Drama: Identity Formation, Marriage and Social Conflict in Ezra 9 and 10 (New York, Bloomsbury, 2013), 49; Ntozakhe Cezula, "Identity Formation and Community Solidarity: Second Temple Historiographies in Discourse with (South) African Theologies of Reconstruction," (Ph.D. thesis, University of Stellenbosch, 2013), 91.

24 See Neh 9:37; John L. Berquist, Judaism in Persia's Shadow: A Social and Historical Approach (Minneapolis, Fortress Press, 1995), 144; Brueggemann, Great Prayers, 109; Cezula, "Identity Formation," 127. 
both $\mathrm{D}$ and $\mathrm{P}$, among other sources. In the contextual reading of earlier sources, $\mathrm{H}$ appealed to ideals of social justice. Interestingly, there may be parallels between $\mathrm{H}$ and the Latino/a biblical critics of the HB. Thus, the way $\mathrm{H}$ re-read both $\mathrm{D}$ and $\mathrm{P}$ to his addressees in the post-exilic period throws light on how a Latino/a biblical critic may re-read Lev 25:8-55, a point to which we now turn.

\section{FROM H TO LATINO/A BIBLICAL CRITICS}

The main argument of this paper is that H's concern for social justice for the working-class people can throw light on the reading of the Lev 25:8-55, particularly from the perspective of the Latino/a biblical criticism, and more importantly, that such a reading could also have implications for the workingclass people of South Africa. On this argument, first, the bearing of $\mathrm{H}$ on the Latino/a biblical criticism and Ernesto "Che" Guevara's discourse of the experiences of the working-class people is critical. Second, the implications of H's concern for social justice for South Africa constitute an important point. On a hermeneutical level, Latino/a biblical criticism

posit the community as the foundation, optic, and objective of interpretation-imbued by an overriding awareness of marginali-sation, a clarion call for solidarity and liberation, and an unwavering appeal to ideals of social justice. ${ }^{25}$

Guided by the latter hermeneutical tool, this article therefore teases out the concerns for social justice for the working-class people in the text under consideration as well as in the South African context.

\section{Relevance of $\mathrm{H}$ to Latino/a Biblical Criticism and Ernesto "Che" Guevara}

That $\mathrm{H}$ used other sources such as $\mathrm{D}$ and $\mathrm{P}$, among others, to create a revised material shows the way $\mathrm{H}$ sought to articulate certain views and positions in his own terms. In that way, unlike D who may have served the interest of the rich élite, $\mathrm{H}$ opted to be in solidarity with the marginalised people, specifically the poor and the working-class people with a view to pursue their interest. Like $\mathrm{H}$, the Latino/a biblical critics seek to articulate their own positions in their own terms in solidarity with the marginalised people with a view to pursue justice. As Segovia excellently perceived, behind the exercise of Latino/a biblical criticism is a "desire for self-assertion and self-introjection, in the light of the practices of marginalization and erasure that govern their reality and experience in society and culture." ${ }^{, 6}$ Furthermore, as Segovia submitted, the Latino/a biblical

25 Fernando F. Segovia, "Introduction: Approaching Latino/a Biblical Criticism: A Trajectory of Vision and Missions," in Latino/a Biblical Hermeneutics: Problematics, Objectives, Strategies (ed. Franscisco Lozada Jr. and Fernando F. Segovia; Atlanta: Society of Biblical Literature Press, 2014), 37.

26 Segovia, "Approaching Latino/a Biblical Criticism," 3. 
criticism place the modern context at the heart of biblical interpretation, and more importantly that this hermeneutical tool teases out the ideals of social justice in the Bible and modern context. ${ }^{27}$ In other words, a modern reader of Lev 25:8-55, one who employs Latino/a critical tools, may view H's concern for social justice in vv. 10, 39-40 and 54-55 as appealing, mainly because it offers liberating possibilities to the poor and the working-class people.

As Carroll argues, Latino/a biblical criticism is critical of the ideological contestations that are embedded in ancient texts. ${ }^{28}$ Teasing out both the oppressive and liberating ideologies of authors and redactors of ancient text becomes important for a Latino/a biblical critic. The manner in which H substituted D's noun "שְׁמְָָה "remission" with the word "liberty" and "Jubilee" in Lev 25:10 in order to juxtapose the issues of the return of land and the release of debt-slaves would enjoy a positive reception among the Latino/a biblical critics. Furthermore, H's re-conceptualisation of slavery, more specifically the portrayal of the root cause of hard labour or slavery and indebtedness as being the loss of land, would be fit to what would be an ideological reading of vv. 35-54. In addition, drawing on Vanderhooft and Smith-Christopher, Rugwiji observes "the ideology of subjugating the Judeans in Babylonia included some kind of "cheap labour' provision as well as possibilities of other kinds of ill-treatment (Is 52:5; Jr 51:6-7; Lm 3:1-9; Ps 137)."29 Based on the view that H refutes D's conceptualisation of slavery, which was most likely known in the exilic context, H's call for the liberation of the working-class people who were also exploited in postexilic Yehud would be highlighted by the Latino/a biblical critics. Such a call would be highlighted mainly because it shows an instance in which $\mathrm{H}$ refuted an ideology which was oppressive to the working-class people.

Unlike Segovia and Carroll's contribution on Latino/a biblical criticism, Botta's illustration of the way the HB may be holistically approached with Latino/a critical tools, adds a curious dimension to Latino/a biblical criticism. For instance, he argues that this holistic approach leads to a reading of the claim that "the Lord has anointed me; he has sent me to bring good news to the oppressed" in Isa 61:1-2 in the following manner: "the good news is for the social class comprising the materially oppressed only and never for the social class of the oppressors." ${ }^{, 30}$ Based on the preceding argument, it becomes clear

27 Segovia, "Approaching Latino/a Biblical Criticism," 37.

28 M. Daniel Carroll R., "Reading the Bible through Other Lenses: New Vistas from a Hispanic Diaspora Perspective," in Global Voices: Reading the Bible in the Majority World (ed. Craig S. Keener and M. Daniel Carroll R.; Massachusetts: Hendrickson Publishers Marketing, LLC, 2013), 9-10.

29 Rugwiji, “Appropriating Judean," 48-49.

30 Alejandro F. Botta, "What Does It Mean to Be a Latino Biblical Critic? A Brief Essay," in Latino/a Biblical Hermeneutics: Problematics, Objectives, Strategies (ed. Franscisco Lozada Jr. and Fernando F. Segovia; Atlanta: Society of Biblical Literature Press, 2014), 116. 
that a Latino/a biblical critic is mindful of the social class dynamics that are embedded in a biblical text. No doubt, social class dynamics are evident in Lev 25:8-55. As Scheffler excellently perceived, the Israelite deportees to Babylonia were the wealthy class who continued to be economically active. ${ }^{31}$ Additionally, Israelites who were deemed to be offering "cheap labour" were also present in Babylonia. Furthermore, as shown earlier, the argument that the concept of release could have been directed to those in authority presumably the exilic élites who were in a position to influence the struggle for liberation, reveals a social class. In this case, the addressees of D in exile were the élites. Likewise, that the addressees of $\mathrm{H}$ were the returning élites who wanted to reclaim land, as Meyer and Grünwaldt have argued, show a social class dynamic in Lev 25:8-55. ${ }^{32}$ Furthermore, D's call for the payment of compensation and the distinction between the houses in villages and walled cities reveals the way $\mathrm{D}$ seem to have favoured the rich élites instead of the struggling farmers. Thus, it makes sense to observe a social class dynamic in Lev 25:8-55. As argued earlier, $\mathrm{H}$ addressed both the poor and the rich but emphasised the plight of the poor. This equally shows a social class dynamic. On the point of the distinction between the houses in villages and walled cities, it may be argued that there were the working-class people of the villages and the wall cities, providing us a clue about the social class dynamics among the working-class people. Moreover, Brueggemann's argument that the Judeans who were treated as slaves in Babylonia were equally treated as slaves - exploited peasants - by the Persian authorities in the post-exilic period, provides a clue about the social class dynamics in Yehud which are embedded in Lev 25:8-55. ${ }^{33}$

Outside of biblical studies, can one find valuable insight from the field of social sciences, and more specifically from a figure that is born in Argentina? In his response to the question: What is the guerrilla fighting for, Guevara states:

We must come to the inevitable conclusion that the guerrilla is a social reformer, who takes up arms responding to the angry protest of the people against their oppressors, and who fights to change the social system that keeps all his unarmed brother in ignominy and poverty. ${ }^{34}$

31 Eben Scheffler, Politics in Ancient Israel (Pretoria: Biblia Publishers, 2001), 135137; cf. Jer 29:5-7.

32 Meyer, Jubilee in Leviticus, 224; Grünwaldt, Das Heiligkeitsgesetz Leviticus, 380381.

33 Brueggemann, Great Prayers, 109; cf. Brueggemann, Cadences of Home, 115; Usue, "Restoration or Desperation," 843; Rugwiji, "Appropriating Judean," 46.

34 Ernesto Che Guevara "The Essence of Guerrilla Struggle (1960)," in Che Guevara and the Cuban Revolution: Writings and Speeches of Ernesto Che Guevara (ed. David Deutschmann; Sydney: Pathfinder/Pacific and Asia, 1987), 78-79. 
Although Guevara is mostly associated with warfare, this paper does not intend to instigate a form of guerrilla fighting which may lead to loss of lives. However, drawing on Guevara's definition of guerrilla fighting, a protest against the oppression of the working-class people which seeks to change the social system that keeps them in ignominy is supported. Interestingly, Guevara makes it clear that the struggle of the people in Cuba for instance aimed primarily "at changing the social form of land ownership; in other words, the guerrilla fighter is above all an agrarian revolutionary. He interprets the desire of the great peasant ${ }^{35}$ masses to be owners of the land . . ."36 For Guevara, the liberation of the working-class people is intrinsically juxtaposed to agrarian reforms. In a similar manner, particularly from an ideological point of view, $\mathrm{H}$ re-conceptualised the idea of slavery by linking the issues of the return of land and the release of debt-slaves.

Furthermore, from an intertextual perspective, the reading of the theme of "slaves" in Lev 25:8-55 in the light of Neh 9:6-37, a post-exilic text, showed the way the Persian imperialistic government treated the Judeans as slaves and exploited their economic resources in post-exilic Yehud. Thus, H's concern for social justice also refuted the imperialism. On this point, the rejection of imperialism, that is, the way the Persian Empire ill-treated the Judeans, fits to Segovia's postcolonial hermeneutic which stand in continuity with Latino/a biblical criticism. ${ }^{37}$ In his hermeneutic, Segovia is critical of imperialism in the biblical texts as well as in modern society. Likewise, Guevara argues that the redress of socio-economic injustice includes a struggle with imperialism. ${ }^{38}$

Furthermore, drawing on Fidel Castro's speech of April 11, 1962, Guevara bases his response to the challenges of the working-class people on the Marxist-Leninist theoretical framework. In such a speech Castro states that Marxism-Leninism is about "the desire to combat the distress of the proletariat, the desire to fight poverty, injustice, suffering, and all the exploitation of the proletariat . ..."39 Therefore, a Latino/a biblical critic as well as an OT scholar who draws on Guevara's discourse on the working-class people would identify

35 In this paper the word "peasant" is deliberately used interchangeably with the phrase "working-class people," and more especially that peasants are also employees.

36 Guevara, "Essence," 79; cf. Ernesto Che Guevara, "The Responsibility of the Working Class in our Revolution (June 18, 1960)," in Che Guevara and the Cuban Revolution: Writings and Speeches of Ernesto Che Guevara (ed. David Deutschmann; Sydney: Pathfinder/Pacific and Asia, 1987), 104.

37 Fernando F. Segovia, "Biblical Criticism and Postcolonial Studies: Toward a Postcolonial Optic," in The Postcolonial Biblical Reader (ed. Rasiah S. Sugirtharajah; Oxford: Blackwell Publishing, 2006), 37.

38 Ernesto Che Guevara, "Building a Party of the Working Class (1963)," in Che Guevara and the Cuban Revolution: Writings and Speeches of Ernesto Che Guevara (ed. David Deutschmann; Sydney: Pathfinder/Pacific and Asia, 1987), 191.

39 Fidel Castro in Guevara, "Building a Party," 194. 
with the way $\mathrm{H}$ addressed the issues of the distress of the proletariat, poverty, injustice, suffering, and the exploitation of the proletariat in post-exilic Yehud. The deliberate use of the term "slaves" which speaks to the way the Judeans were treated in the workplace and the instruction that the poor brother should not work as a slave but as שָׁכִיר "hired worker" (v. 40) show how H addressed the struggles of the proletariat. $\mathrm{H}$ puts forward a case for the liberation of the employee in vv. 40-41with the argument that in the Jubilee Year the hired worker should return to both his family and productive land.

The issue of a context adds a curious dimension to both H's use of D and $\mathrm{P}$ in post-exilic Yehud as well as the reading of ancient texts by the Latino/a biblical critics. It is therefore important to illustrate the implication of H's concern for social justice for the working-class people of South Africa.

\section{Implications of H's Concern for Social Justice for South Africa}

The issue of whether the exiles were slaves, prisoners, hard labourers or forced labourers reminds one of the liberation songs, Lelizwe, "This Land." In the song, the working-class people are portrayed as living working under adverse realities. To date, the hired workers in the South African mines and farms continue to protest against low wages. For instance, Masenya (ngwan'a Mphahlele) holds that some of the protesting miners - the so-called workingclass "slaves" in Marikana - are "stuck in the perpetual cycle of poverty which was inherited from the inequities of the apartheid era." 40 This view is convincing because it is confirmed by the persistent protest of the working-class people in South Africa. With respect to Lev 25:8-55, one wonders why would the idea of "remission" and the "release of slaves" be mentioned in Lev 25:10, 39-40 and 54 if both the exiles and the Judeans in post-exilic Yehud did not experience any harsh realities that necessitated a call for liberation. Therefore, Lev 25:8-55 may be read in the South African context as a protest against the socioeconomic injustice experienced by the so-called slaves, that is, the workingclass people.

The theme of indebtedness in the Israelite Jubilee legislation triggers the interest in the indebtedness of the working-class people of South Africa which may be linked to the lack of productive land, skills and capital. Edozien argues that "the end of political apartheid is ultimately meaningless without the end of economic apartheid" which South Africa is currently experiencing. ${ }^{41}$ Edozien

\footnotetext{
40 Madipoane Masenya (ngwan'a Mphahlele), “Eating the Louse and its Larva! The Indignity of Poverty as Embedded within Selected African and Old Testament Proverbs," Scriptura 111/3 (2012): 453.

41 Joseph Edozien, "Ending Economic Apartheid," p. 1 [cited 20 February 2014]. Online: http://www.sane.org.za/docs/eeashortversion.pdf. Cf. Ndikho Mtshiselwa, "A Post-Apartheid Nation in Chains? Relevance of Lucky Dube's Mickey Mouse Freedom in Reconfiguring Forms of Oppression in South Africa," StHistE 40/1 (2014):
} 
argues that many working-class people are trapped not only in debt but also in an economic system that does not allow them to own resources. ${ }^{42}$ For instance, the so-called possessions, that is, the cars and houses of many middle-class workers which in fact belong to the banks because of loan conditions validate the view that this class of people are trapped in debt. ${ }^{43}$ Moreover, the issue of financial credibility of the borrowers which demands evidence of a track record as a paying creditor from the poor is an impediment to socio-economic-redress particularly in light of South African history of black people being dispossessed of their assets (land). Therefore, an African critique of indebtedness in South Africa would insist on land redistribution that privileges both the élites and the working-class people. This critique is inspired by theme of redistribution of land in the Jubilee legislation which sought to address indebtedness and socioeconomic injustice.

\section{CONCLUSION}

The socio-economic inequities which persist in South Africa today, and more specifically experienced by the working-class people cause concern to the present hermeneut. Thus, the interest of this article lied at reading Lev 25:8-55 with the view of navigating liberating possibilities for the working-class. On this point, the article finds that if Lev 25:8-55 is read from the perspective of the Latino/a biblical criticism, H's concern for social justice for the workingclass people throws light on the reading of the ancient texts. Significantly, such a reading also has implications for the working class people of South Africa. In the end, the present paper calls for socio-economic redress on land redistribution and consequently to poverty alleviation in South Africa.

\section{BIBLIOGRAPHY}

Balentine, Samuel E. Leviticus. Louisville, Ky.: Westminster John Knox Press, 2002. Bartos, Michael and Bernard M. Levinson. "This is the Manner of the Remission": Implicit Legal Exegesis in 11QMelchizedek as a Response to the Formation of the Torah." Journal of the Biblical Literature 132/2 (2013): 351-371.

Berquist, John L. Judaism in Persia's Shadow: A Social and Historical Approach. Minneapolis, Fortress Press, 1995.

Botta, Alejandro F. "What Does it Mean to Be a Latino Biblical Critic? A Brief Essay." Pages 107-120 in Latino/a Biblical Hermeneutics: Problematics, Objectives, Strategies. Edited by Franscisco Lozada Jr. and Fernando F. Segovia. Atlanta: Society of Biblical Literature Press, 2014.

70-71; Vincent N. N. Mtshiselwa, "Re-Reading the Israelite Jubilee in Leviticus 25:855 in the Context of Land Redistribution and Socio-Economic Justice in South Africa: An African Liberationist Perspective," (Ph.D. thesis, University of South Africa, 2015), 287, 316.

42 Edozien, "Ending Economic Apartheid," 2.

43 Mtshiselwa, "A Post-Apartheid Nation," 70-71. 
Brueggemann, Walter. Cadences of Home: Preaching Among Exiles. Louisville, Ky.: Westminster John Knox Press, 1997. . Great Prayers of the Old Testament. Louisville, Ky.: Westminster John Knox Press, 2008.

Carroll R. M. Daniel. "Reading the Bible through Other Lenses: New Vistas from a Hispanic Diaspora Perspective." Pages 5-26 in Global Voices: Reading the Bible in the Majority World. Edited by Craig S. Keener and M. Daniel Carroll R. Massachusetts: Hendrickson Publishers Marketing, LLC, 2013.

Cezula, Ntozakhe. "Identity Formation and Community Solidarity: Second Temple Historiographies in Discourse with (South) African Theologies of Reconstruction." Ph.D. thesis, University of Stellenbosch, 2013.

Collins, John J. Introduction to the Hebrew Bible. Minneapolis: Fortress Press, 2004. Edozien, Joseph. "Ending Economic Apartheid.” Page 1. Cited 20 February 2014. Online: http://www.sane.org.za/docs/eeashortversion.pdf.

Eskenazi Tamara C. and Andrea L. Weiss. The Torah: A Women's Commentary. New York: URJ Press and Women of Reform Judaism, 2008.

Gerstenberger, Erhard S. Leviticus: A Commentary. Louisville, Ky.: Westminster John Knox Press, 1996.

Gorman, Frank H. Divine Presence and Community: A Commentary on the Book of Leviticus. Grand Rapids: Wm. B. Eerdmans Publishing Company, 1997.

Grünwaldt, Klaus. Das Heiligkeitsgesetz Leviticus 17-26: Ursprüngliche Gestalt, Tradition und Theologie. Beiheft zur Zeitschrift für die alttestamentliche Wissenschaft 271. Berlin: Walter de Gruyter, 1999.

Guevara, Ernesto C. "The Essence of Guerrilla Struggle (1960)." Pages 76-84 in Che Guevara and the Cuban Revolution: Writings and Speeches of Ernesto Che Guevara. Edited by David Deutschmann. Sydney: Pathfinder/Pacific and Asia, 1987.

. "The Responsibility of the Working Class in our Revolution (June 18, 1960)." Pages 103-123 in Che Guevara and the Cuban Revolution: Writings and Speeches of Ernesto Che Guevara. Edited by David Deutschmann. Sydney: Pathfinder/Pacific and Asia, 1987.

. "Building a Party of the Working Class (1963)." Pages 187-195 in Che Guevara and the Cuban Revolution: Writings and Speeches of Ernesto Che Guevara. Edited by David Deutschmann. Sydney: Pathfinder/Pacific and Asia, 1987.

Joosten, Jan. People and Land in the Holiness Code: An Exegetical Study of the Ideational Framework of the Law in Leviticus 17-26. Supplements to Vetus Testamentum 67. Leiden: Brill, 1996.

Knohl, Israel. The Sanctuary of Silence: The Priestly Torah and the Holiness School. Minneapolis: Fortress Press, 1995.

Leuchter, Mark. "The Manumission Laws in Leviticus and Deuteronomy: The Jeremiah Connection.” Journal of Biblical Literature 127/4 (2008): 635-653.

Levinson, Bernard M. "The Birth of Lemma: The Restrictive Reinterpretation of the Covenant Code's Manumission Law by the Holiness Code (Leviticus 25:44-46)." Journal of Biblical Literature 124/4 (2005): 617-639. 
Masenya (ngwan'a Mphahlele), Madipoane. "Eating the Louse and Its Larva! The Indignity of Poverty as Embedded within Selected African and Old Testament Proverbs." Scriptura 111/3 (2012): 452-459.

Meyer, Esias E. The Jubilee in Leviticus 25: A Theological Ethical Interpretation from a South African Perspective. Münster: LIT Verlag, 2005. . "Dating the Priestly Text in the Pre-Exilic Period: Some Remarks about Anachronistic Slips and other Obstacles." Verbum et Ecclesia 31/1 (2010): 1-6. . "From Cult to Community: The Two Halves of Leviticus." Verbum et Eclesia 34/2 (2013): 1-7.

. "Returning to an Empty Land: Revisiting My Old Argument about Jubilee."

Old Testament Essays 27/2 (2014): 502-519.

Milgrom, Jacob. "The Antiquity of the Priestly Source: A Reply to Joseph

Blenkinsopp.” Zeitschrift für die Alttestamentliche Wissenschaft 111 (1999): 1022.

Moffat, Donald P. Ezra's Social Drama: Identity Formation, Marriage and Social Conflict in Ezra 9 and 10. New York, Bloomsbury, 2013.

Mosala, Itumeleng J. "Land, Class and the Bible in South Africa Today." Journal of Black Theology in South Africa 5/2 (1991): 40-46.

Mott Stephen and Ronald J. Sider. "Economic Justice: A Biblical Paradigm." Transformation: An International Journal of Holistic Mission Studies 17/2 (2000): 50-63.

Mtshiselwa, Ndikho, "A Post-Apartheid Nation in Chains? Relevance of Lucky Dube's Mickey Mouse Freedom in Reconfiguring Forms of Oppression in South Africa Today." Studia Historiae Ecclesiasticae 40/1 (2014): 57-76.

Mtshiselwa, Vincent N. N. "Re-Reading the Israelite Jubilee in Leviticus 25:8-55 in the Context of Land Redistribution and Socio-Economic Justice in South Africa: An African Liberationist Perspective." Ph.D. thesis, University of South Africa, 2015.

Nihan, Christophe. From Priestly Torah to Pentateuch: A Study in the Composition of the Book of Leviticus. Tübingen: Mohr Siebeck, 2007.

."Resident Aliens and Natives in the Holiness Legislation." Pages 111-134 in The Foreign and the Law: Perspectives from the Hebrew Bible and the Ancient Near East. Edited by Reinhard Achenbach, Rainer Albertz and Jakob Wöhrle. Wiesbaden: Harrassowitz Verlag, 2011.

Otto, Eckart. "The Holiness Code in Diachrony and Synchrony in the Legal Hermeneutics of the Pentateuch." Pages 135-156 in The Strata of the Priestly Writings: Contemporary Debate and Future Directions. Edited by Sarah Shectman and Joel S. Baden. Zürich: Theologischer Verlag Zürich, 2009.

Rooker, Mark F. Leviticus. The New American Commentary 3A. Nashville: Broadman and Holman Publishers, 2000.

Rugwiji, Temba. "Appropriating Judean Post-Exilic Literature in a Postcolonial Discourse: A Case for Zimbabwe." Ph.D. thesis, University of South Africa, 2013.

Scheffler, Eben. Politics in Ancient Israel. Pretoria: Biblia Publishers, 2001.

Schwartz, Baruch J. The Holiness Legislation: Studies in the Priestly Code. Jerusalem: Magnes; 1996. 
Segovia, Fernando F. "Biblical Criticism and Postcolonial Studies: Toward a Postcolonial Optic." Pages 33-44 in The Postcolonial Biblical Reader. Edited by Rasiah S. Sugirtharajah. Oxford: Blackwell Publishing, 2006. . "Introduction: Approaching Latino/a Biblical Criticism: A Trajectory of Vision and Missions." Pages 1-39 in Latino/a Biblical Hermeneutics: Problematics, Objectives, Strategies. Edited by Franscisco Lozada Jr. and Fernando F. Segovia. Atlanta: Society of Biblical Literature Press, 2014.

Stackert, Jeffrey. "Distinguishing Innerbiblical Exegesis from Pentateuchal Redaction: Leviticus 26 as a Test Case." Pages 369-386 in The Pentateuch: International Perspectives on Current Research. Edited by Thomas B. Dozeman, Konrad Schmid and Baruch J. Schwartz. Tübingen: Mohr Siebeck, 2011.

. "Composition Strata in the Priestly Sabbath: Exodus 31:12-17 and 35:1-3." The Journal of Hebrew Scripture 11 (2011): 1-21.

Trevaskis, Leigh M. Holiness, Ethics and Rituals in Leviticus. Sheffield: Sheffield Academic Press, 2011.

Usue, Emmanuel O. "Restoration or Desperation in Ezra and Nehemiah? Implications for Africa." Old Testament Essays 20/3 (2007): 830-847.

Dr. Ndikho Mtshiselwa, Department of Biblical and Ancient Studies, University of South Africa. Email: mtshivnn@unisa.ac.za. 